\title{
Youths Entrepreneurship: A Panacea to Employment Generation and Sustainable Development in Nigeria
}

Tope Alabi

DOI:10.36108/NJSA/7102/51(0290)

\section{Abdulmumin Ibrahim}

Department of Sociology

University of Abuja

Abuja, Nigeria

E-mail: Luckytope4j@yahoo.co.uk, Ibrahimabdulmumin28@yahoo.com

\begin{abstract}
The role of youth entrepreneurship in the economic development has been well recognized in the literature. In a liberal market economy, entrepreneurs coordinate economic activities in such a way that factors of production are moved to areas in which they are fully utilized while they also bear risk and uncertainty in the process of arbitrage which eventually leads to the expansion of the production possibility curve, socio-economic growth and development. In contemporary time, the movement by nations of the world towards a neo-liberal economic framework has elevated the study of determinants of entrepreneurship to the centre stage. It has been established from past studies that entrepreneurship especially among youths has become antidote to joblessness and underdevelopment. This paper, therefore, examines the role of youth entrepreneurship development as a panacea to sustainable development in Nigeria. The paper suggested that if Nigeria in her quest to reducing unemployment and poverty must incorporate entrepreneurship tutoring into the curriculum at all levels of education with a view to promoting self-employment among graduates and youths generally.
\end{abstract}

Keywords: Unemployment, entrepreneurship tutoring, skills acquisition, economic development

\section{Introduction}

It is increasingly recognized by both government and development experts the important role of entrepreneurship in the process of socio-economic development of societies (Kurya, 2006). It is central to the progress of any nation given its contributions to the economy by creating jobs and generating employment, increasing productivity, creating wealth and value added to sustain growth and overall societal development. Entrepreneurship (especially among the youths) has potentials for developing human resources, through modern and traditional apprenticeship in different trades and occupations and thus, improves economic independence of young people (Abor, 2008). While there is no agreed definition of 'youth', For example, youth unemployment is usually measured amongst those aged 16-24, whilst the EU (2009) defines young people aged 15-29. 
Entrepreneurship has gained national as well as global recognition as a significant force towards propelling a country to greater heights, thereby emancipating the country from social and economic predicaments. Entrepreneurship is a prime source of innovation, a large generator of employment and features prominently in government economic policies at both local and international levels.

In the light of these perceived benefits of entrepreneurship in growing an indigenous enterprise culture, many development scholars have advocated the use of entrepreneurship in accelerating the process of socio-economic growth and sustained development. This paper therefore takes a critical look at the role of youth entrepreneurship in bringing about sustainable development in Nigeria.

\section{Youth Unemployment and Entrepreneurship in Nigeria}

It has been established from literature and past studies that entrepreneurship especially among youths has been an antidote to joblessness and general underdevelopment (Andow 2010;Alabi, Bahal and Alanana 2014). The role of the youth in national development cannot be over emphasized. Youths with their enormous strength and youthfulness, passion and knowledge constitute great assets to the development of any nation. Looking at the population structure of Nigeria, one will understand the important role that youths play. The Nigerian population is youthful and has grown from 22.5 million in 1991 to 52.3 million in 2012 . Young people currently comprise over $25 \%$ of the Nigerian population (National population commission, 2006).

According to the NPC (2006) more than half of Nigerian population are under the age of 30 . Thus, Nigeria's population structure is youthful with implication for its economy (Okafor, 2011). However, the Nigerian youths are said to be confronted with poverty and unemployment, lack of capacity and essential productive skills needed for employment to move the economy forward. Nigeria like most developing nations of the world is faced with myriad of problems and harsh economic realities including poverty and unemployment especially of the youths. The problem of youths' unemployment in Nigeria is said to be traceable to the disequilibrium between labour market requirements and lack of essential employable skills by young people (Dabalen, 2000 and Alabi, 2013). This obvious critical skills gaps inhibit the development of youths in general in Nigeria.

As observed by Oba (2012), lack of marketable skills from unemployment generation and poverty reduction in Nigeria are other challenges facing the youths' contributions to national development. This reality leaves Nigerian youths without any sustainable means of livelihood (Ibid, 2012). Similarly, Adegbite et al. (2006) noted that technical entrepreneurial talent that involves the establishment and management of manufacturing industries for productive activities in the real sector of the economy is lacking in Nigeria. However, a World Bank study by Nils-Henrik and Morch (1995) proposed a contrary view that entrepreneurial talent is indeed available but that the economic 
environment have been such that it does not allow this talent to develop. This points to the fact that, the kind of economic policies that have been followed in the four to five decades after political independence have not always been conducive to private enterprise. This proposition concurs with a third view by Adjebeng-Asem (1989) as cited in Adegbite et al. (2006) that African entrepreneur is alive and well, but that he/she rather than undertaking manufacturing business (technical entrepreneurship) has been diverted to nonproductive, rent and contract-seeking activities which researches have referred to as commercial entrepreneurship.

The problems of unemployment as experienced by the youths and even the uneducated but skilled youths have been more pathetic in Nigeria despite various policy measures and intervention strategies by the government (Awogbenle and Iwnamadi, 2010). After three decades of Structural Adjustment programme (SAP), Commercialization and Privatization of ailing state-owned enterprises and National Directorate of Employment (NDE), the contributions of the initiatives towards Youths Economic Empowerment is still every dismal (Adegbite et al., 2006). The neglect of agriculture to the background by the government has also added to the problem of youth's unemployment in the region. As a result of the oil boom in 1970s and early 1980 s, a combination of increasing petroleum production and rising price of petroleum products brought easy and wind fall earnings, which diverted Nigeria's attention from developing other sectors of the economy and encourage the neglect of agriculture (Abdulrahim, 2009).

\section{Challenges of Youth's Entrepreneurship Development in Nigeria}

The problem militating against the growth and development of Entrepreneurship in Nigeria as rightly observed by Sagagi (2010) is that over the years, states intervention on enterprise development capable of generating massive jobs were mainly political and not based on objective analysis of the key sectors. Another similar but not the same with the earlier identified problem as observes by (Sagagi, 2010) is that states lack a development agenda which will target few high potential sectors capable of producing massive growth and employment thereby putting the states back in their former developmental pedestals. There are certain binding constraints to operating businesses in Nigeria which tend to limit the ability of the country to create greater value than it could otherwise produce: failures in markets for agricultural inputs and outputs restrict productivity and growth thereby limiting the potentials of farmers to obtain necessary income to invest in higher value activities (DFID, 2006 in Sagagi, 2010). According to Tsauni, (2005) and Sagagi (2006) other factors limiting the development of manufacturing and services sectors are decaying infrastructure, inefficient institutions and lack of policy direction among others.

On the other hand, Aturu-Aghedo (2008) posits that the state participation in Nigerian Economic Management has been bedevilled by inefficiency, tardiness, inconsistency in decision - making and implementation due to 
bureaucracy, and inefficient allocation of economic resources. According to most so call government intervention and programmes on entrepreneur over the years were politically motivated lacking all forms of pragmatic and objective bases. Sagagi (2010) asserts that in order to significantly reduce poverty and unemployment in Nigeria, the growth agenda to be pursued should be the one with potentials for massive business creation, higher wages and higher value goods and services.

Other limiting factors on the part of the youth Entrepreneurs as observed by (Auyo, 1990) include; Lack of managerial and Technical Skills; Inadequate Preparation; Inadequate Capital; Neglect/inadequate Supervision, Lack of separation between business and personal accounts; Other factors-unforeseen happenings or the act of God.

According to Beck et al. (2009); Ganbold (2008) and De la Torre et al. (2009), improving access to finance entails improving the degree to which financial services are available to all at a low price. Notwithstanding the importance and contribution of SMEs in nation building, the enterprises face serious difficulties and harsh condition when trying to obtain finance, especially from the formal financial institutions. Access to financing has continued to be a problem for SMEs. For example, Sanusi (2003) and Olutunla and Obamiyi (2008) observe that SME's access to formal financial system in Nigeria is very limited. Charles (2007) found that accessibility to finance and good management are central to SMEs' growth and development.

\section{Conclusion}

From the foregoing, it is clear that for Nigeria to achieve a holistic development cutting across economic as well as social spheres, youths entrepreneurship development should be prioritized. Therefore, systematic support for entrepreneurial endeavour is required in the area of accessibility to credit facilities. Unlike large-scale entrepreneurs, most of these small-scale entrepreneurs need facilitation for networking, resource mobilization, lower rates of interest, proxies for collateral and availability of information. Funds are normally limited as most beneficiaries have to rely on their own savings or borrow from relatives.

Non-financial assistance included organizing small business management training, workshops and seminars, technical assistance and networks (trade fairs, industry shows). Entrepreneurs need support services in addition to financial assistance to facilitate economic growth. In particular, entrepreneurs need support to enable them conduct market studies, prepare business plans and access loans.

\section{References}

Alabi, T. (2014) Youths' Unemployment and Crime Control: An Analysis of Nigerian Experience. European Scientific Journal. 10(2): 301-312. ISSN: 1857-7431. 
Alabi, T. and Alanana, O.O. (2012) Unemployment and Poverty: The Twin Fertilizer for Youth Criminality. Global Journal of Social Sciences, 2(2).

Alabi, T., Bahal, M. and Alanana, O.O. (2014) Entrepreneurship Education: A Panacea to the Graduate Unemployment in Nigeria. Journal of Sustainable Development in Africa. Pp. 65.

Abdulrahim, Y. (2009) "Improving Agro-Produce Market Potentials for enhanced standard of living of the Nigerian Farmers", a paper presented at the Global Agric. Exhibition Kano: organized by KACCIMA, 16-20, April.

Abor, J. (2008) "Determinants of the Capital Structure of Ghanaian Firms, "AERC Research Paper 1799 Kenya. African Economic Research Consortium, 179: 13-27.

Abuja Securities and Commodity Exchange (2006) "An overview." Abuja: ASCE Publication January.

Adegbite, S.A., Ilori, M.O., Irefin, I.A., Abereijo, I.O. and Aderemi, H.O.S. (2006) Evaluation of the Impact of Entrepreneurial Characteristics on the Performance of Small Scale Manufacturing Industries. Nigeria Journal of Asia Entrepreneurship and Sustainability, 3(1).

Aiberti, F. (1999) "Entreprenurship Education. Scope and Theory." In Salvato, C.J., Davidson, P. and Persson, A. (Eds.). Entrepreneurial Knowledge and Learning Conceptual Advances and Directions for Future Research. JIBS Research Reports No. Joukoping: internal Business School, 6: 64-84.

Andow, A.H. (2010) "Impact of Entrepreneurial Skills Development Programmes on the Performance of Women Entrepreneur in Kaduna State". Unpublished Seminar paper, Kaduna: Nigeria Defences Academy.

Aturu-Aghedo, C. (2008) Human Resource Planning. Publication of National Open University of Nigeria (NOUN), Lagos: Lagos Lucky Star Printing Ent.

Baron, R.A. (2006) Opportunity recognition as pattern recognition how Entrepreneurs "connect the dots" to identify new business opportunities Academy of Management Perspectives, 20(1): 104-9.

Best, J.W. and Khan, J.V. (2003) Research in Education. $9^{\text {th }}$ ed. New Delhi: Prentice-Hall.

Borg, W.R., Gall, J.P. and Gall, M.D. (2005) Applying Education Research A. Practical Guide, 5th ed. Boston Allyn and Bacon.

Bureau of Public Service Reform (2004) Pre-Retirement Individual Development and Empowerment (PRIDE) Participants Handbook Abuja www.Bpsr.gov.ng.

Fernandez, R., Konigs, S. and Minea, A. (2015) NEET Youth in the Aftermath of the Crises. OECD Social, Employment and Migration Working Papers, No. 6.

DFID (2004) Promoting Pro-poor Opportunities through commodity markets (Prop COM). Draft memorandum revised, April.

Diabelen, A., Oni, B. and Adekola, A. (2000) Labour market prospects for University graduates in Nigeria Washinton D.C: World Bank. 
Donald, L.S. (2000) 'The Theory of Entrepreneurship" world Essay Drucker, P.F. (1985). Innovation and Entrepreneurship: Principal and Practice new York Harper and Row Publishers.

Duke, O.O. (2005) "Mainstreaming the Nigerian South Bi National Commission (BNC) into the National Economy Empowerment and Development Strategy (NEEDS)" Abuja FGN.

Duze, M.C., Mohd, H. and Kiyawa, I.A. (Eds.) (2008) Poverty in Nigeria: Causes, Manifestation and Alleviations Strategies, London: Adomis and Abeey Publishers Ltd.

Economic Development (2010) "History of Entrepreneurship Theory." In Technopreneurial. com pp. 1-3. http/entrepreneurship.

Effiom, D.D. (2008) "Impact of Banking Sector Reform on Investment in Nigeria, Unpublished M.Sc. dissertation, Kano: Bayero University Epkenyoung, D.B. (1982), Entrepreneurship Development Programme: which model for Nigeria?" NASMET, 3(2).

Emanuel, I. (2006) "A Regime of Reforms: Implication and Challenges for Human Resource Practitioners", Abuja: IPM Publishers.

Fatunla Grace T. (2010) Entrepreneurship Development in Nigeria http//www. Geogle.Com./Search.

Fayolle, A. (2004) Value Creation in Changing Students State of mind and Behavior: New Research Approach Measure the Effects of Entrepreneurship Education". U.K: A Study carried out by the Research Unit of Entrepreneurship and Process of Innovation.

FGN (2010) Statistics New, Abuja: Publication of the Federal office of Statistics.

Google (2003) Definition of Entrepreneurship, http://www.Google.com/ Search? G2 define: Entrepreneurship (Retrieved on 28 Nov., 2003).

Gouws, E. (2002) "Entrepreneurship Education: Implication for Teacher Training; SATHE/SATHO, 16(2).

Igbo, C.A. (2006) Developing Entrepreneurship through Entrepreneurship education. Journal of Home Economics Research, (7): 50-54.

Ige, C. (2007) Promoting Entrepreneurship for Economic Development of Nigera, Text of the 2007 C/BN Annual Lecture. Presented at Bankers' House, Lagos.

ILO (2007) Enterprise-based Youth Employment Policies, Strategies and Programmes: Initiative for the development of enterprise and strategies, ILO Skills working paper No. 1.

Johanson, E. (2000) "Determinants of self-employment Duration: Evidence from finish Micro data", Amsterdam: Seminar Paper at the Young Economists Forum.

K/mata, B.A. (2008) "Impact of Entrepreneurship Development Programmes in Facilitating Graduate Self-employment in Nigeria." Unpublished Doctoral Dissertation, Department of Economics. Kano: Bayero University. 
Kurako, D.F. (2005) The Emergence of Entrepreneurship Education: Development and Trends. September.

Kurya, D.F. (2006) Globalization and Sustainable Development: Implications for Nigeria Entrepreneurship. A paper presented at the $4^{\text {th }}$ National Conference on Globalization and sustainable Development organized by college of Education, Azare, 1-4 May. Unpublished.

Kurya, U.L. and Kurfi, A.K. (2010) "The Rose of Entrepreneurship in Reducing Rural Poverty in Sub-Saharan Africa. Readings on African Entrepreneurship, Vol. 1.

Mainoma, M.A. and Aruwa, S.A.S. (2008) Entrepreneurship: The Root of Enterprises. Kaduna: Entrepreneurship Academy Publishing.

Maiwada, D.A. and Yalasai, M.A. (Eds.) (2011) Essentials of Educational Research, Zaria: Proposal writing Zaria: Ahmadu Bello University Press Limited.

Mitra, J. and Sagagi, M.S. (Eds.) (2010) Education Partnership in Africal (EPA) Project Newsletter, BUK - ESSEX, September Issue No. 3.

National Population Commission 2006 Census report. 